\title{
Tidal variability of nutrients in a coastal coral reef system influenced by groundwater
}

\author{
Guizhi Wang ${ }^{1,2}$, Shuling Wang ${ }^{1}$, Zhangyong Wang ${ }^{1}$, Wenping Jing ${ }^{1, \dagger}$, Yi Xu ${ }^{1}$, Zhouling Zhang ${ }^{1}$, Ehui Tan ${ }^{1}$, and \\ Minhan Dai ${ }^{1,2}$ \\ ${ }^{1}$ State Key Laboratory of Marine Environmental Science, Xiamen University, Xiamen, 361102, China \\ ${ }^{2}$ College of Ocean and Earth Sciences, Xiamen University, Xiamen, 361102, China \\ $\dagger$ deceased
}

Correspondence: Guizhi Wang (gzhwang@xmu.edu.cn)

Received: 21 April 2017 - Discussion started: 8 May 2017

Revised: 3 December 2017 - Accepted: 15 January 2018 - Published: 20 February 2018

\begin{abstract}
To investigate variation in nitrite, nitrate, phosphate, and silicate in a spring-neap tide in a coral reef system influenced by groundwater discharge, we carried out a timeseries observation of these nutrients and ${ }^{228} \mathrm{Ra}$, a tracer of groundwater discharge, in the Luhuitou fringing reef at Sanya Bay in the South China Sea. The maximum ${ }^{228} \mathrm{Ra}$, $45.3 \mathrm{dpm} 100 \mathrm{~L}^{-1}$, appeared at low tide and the minimum, $14.0 \mathrm{dpm} 100 \mathrm{~L}^{-1}$, appeared during a flood tide in the spring tide. The activity of ${ }^{228} \mathrm{Ra}$ was significantly correlated with water depth and salinity in the spring-neap tide, reflecting the tidal-pumping feature of groundwater discharge. Concentrations of all nutrients exhibited strong diurnal variation, with a maximum in the amplitude of the diel change for nitrite, nitrate, phosphate, and silicate in the spring tide of 0.46 , $1.54,0.12$, and $2.68 \mu \mathrm{M}$, respectively. Nitrate and phosphate were negatively correlated with water depth during the spring tide but showed no correlation during the neap tide. Nitrite was positively correlated with water depth in the spring and neap tide due to mixing of nitrite-depleted groundwater and nitrite-rich offshore seawater. They were also significantly correlated with salinity $\left(R^{2} \geq 0.9\right.$ and $\left.P<0.05\right)$ at the ebb flow of the spring tide, negative for nitrate and phosphate and positive for nitrite, indicating the mixing of nitritedepleted, nitrate- and phosphate-rich less saline groundwater and nitrite-rich, nitrate- and phosphate-depleted saline offshore seawater. We quantified variation in oxidized nitrogen $\left(\mathrm{NO}_{x}\right)$ and phosphate contributed by biological processes based on deviations from mixing lines of these nutrients. During both the spring and neap tide biologically contributed $\mathrm{NO}_{x}$ and phosphate were significantly correlated with regres-
\end{abstract}

sion slopes of $4.60\left(R^{2}=0.16\right)$ in the spring tide and 13.4 $\left(R^{2}=0.75\right)$ in the neap tide, similar to the composition of these nutrients in the water column, $5.43\left(R^{2}=0.27\right)$ and $14.2\left(R^{2}=0.76\right)$, respectively. This similarity indicates that the composition of nutrients in the water column of the reef system was closely related with biological processes during both tidal periods, but the biological influence appeared to be less dominant, as inferred from the less significant correlations $\left(R^{2}=0.16\right)$ during the spring tide when groundwater discharge was more prominent. Thus, the variability of nutrients in the coral reef system was regulated mainly by biological uptake and release in a spring-neap tide and impacted by mixing of tidally driven groundwater and offshore seawater during spring tide.

\section{Introduction}

Coral reefs are considered to be one of the most sensitive and stressed ecosystems occupying the coastal zone (Ban et al., 2014). Groundwater input to coral reefs has been shown to be globally important and carry a significant amount of terrestrially derived nutrients to the reef systems (D'Elia et al., 1981; Paytan et al., 2006; Houk et al., 2013). Groundwater discharge is usually enriched in $\mathrm{N}$ relative to $\mathrm{P}$ with an $\mathrm{N}: \mathrm{P}$ ratio higher than the Redfield ratio, 16:1 (Redfield, 1960), because of more efficient immobilization of $P$ than $N$ in coastal aquifers (Slomp and Van Cappellen, 2004). Such groundwater characterized by a high $\mathrm{N}: \mathrm{P}$ ratio thus could have significant impacts on coastal reef ecosystems, consid- 
ering that benthic marine plants are much more depleted in $\mathrm{P}$, with an $\mathrm{N}: \mathrm{P}$ ratio of about $30: 1$ (Atkinson and Smith, 1983). Cuet et al. (2011) have found that the net community production in a coral-dominated fringing reef at La Réunion, France, is sustained by net uptake of new nitrogen from groundwater and net uptake of phosphate from the ocean.

Groundwater flux onto coral reefs was found to fluctuate with the tidal cycle (Lewis, 1987; Santos et al., 2010). The contribution of groundwater discharge to the nutrient budget of adjacent marine waters of coral reefs varies greatly from one site to another around the globe and at each site varies from one tidal state to another (Paytan et al., 2006). However, there is no study to reveal variation in the composition of nutrients from spring to neap tide in reef systems influenced by groundwater. Therefore, questions are posed. (a) In coral reef systems influenced by groundwater, how do the abundance and composition of nutrients vary from spring to neap tide? (b) What contributes to the tidal variation of nutrients in such a system?

To address these questions, this study examined the nutrient variability in a spring-neap tidal cycle in the Luhuitou fringing reef in Sanya Bay, China, during a dry season. Our previous study showed that tidally driven groundwater discharge affected the carbonate system in the Luhuitou fringing reef (Wang et al., 2014). In this reef system, groundwater discharge played a predominant role during the spring tide, and biological activities (including photosynthesis/respiration and calcification/dissolution) dominated during the neap tide in regulating diurnal variation of the carbonate parameters. Time-series observations of nutrients carried out at the same time as for the carbonate parameters in this reef system made this study possible. The naturally occurring radioactive radium isotope, ${ }^{228} \mathrm{Ra}$, was utilized as a tracer of groundwater discharge in this study.

\section{Materials and methods}

\subsection{Site description}

Sanya Bay is a tropical bay situated at the southern tip of Hainan Island, China, in the northern South China Sea under the influence of the Southeast Asian monsoon (Fig. 1). Seasonal monsoons dominate Hainan Island, with northeast winds in November to March and southwest winds in May to September. Rainfall ranges from 961 to $2439 \mathrm{~mm} \mathrm{yr}^{-1}$ in 1994-2011, with about $80 \%$ precipitation occurring during May to October (Zhang et al., 2013). The coastal reef timeseries station $\mathrm{CT}$ is located at the Luhuitou fringing reef in the southeast of Sanya Bay. There was no rain in the two weeks before our sampling starting on 2 February 2012 and during our 11-day-long sampling period based on data from the nearby meteorological station in the Hainan Tropical Marine Biology Research Station, Chinese Academy of Science. No surface runoff was present during these periods in this
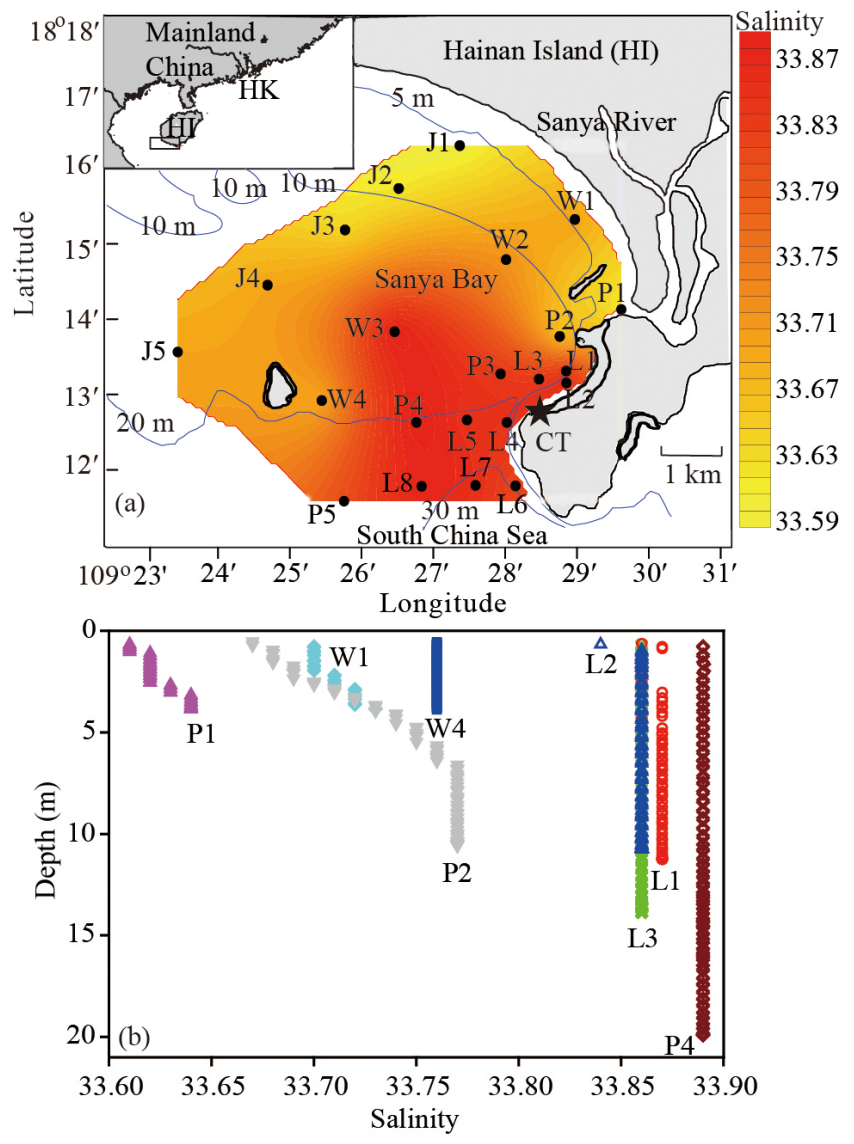

Figure 1. Study area, sampling stations and salinity distribution (a) and vertical profiles of salinity (b) in February 2012 in Sanya Bay, Hainan Island (HI) in the South China Sea. HK represents Hong Kong. CT is the coastal reef time-series station. Salinity data were reported in Wang et al. (2014).

area. Surface salinity in Sanya Bay in our sampling period ranged from 33.60 to 33.89 (Wang et al., 2014). Irregular diurnal tides prevail in Sanya Bay, with a mean tidal range of $0.90 \mathrm{~m}$ and the largest value of $2.14 \mathrm{~m}$ (Zhang, 2001). The Luhuitou fringing reef is a leeward coast with low wave energy in winter (Zhang, 2001). In summer coastal upwelling off the east of Hainan Island mainly induced by the southeast monsoon may extend to this area (Wang et al., 2016). The Holocene deposits of coral debris and biogenic carbonate sands (secondary reef) form the surficial unconfined aquifer around the fringing reef (Zhao et al., 1983), making groundwater a diffuse source of nutrients for the reef system. Macroalgae cover about $60 \%$, on average, of the bottom hard substrates in the Luhuitou fringing reef (Titlyanov and Titlyanova, 2013). Living scleractinian corals were observed in the lower intertidal zone and subtidal zone with coverage of 5-40\% (Titlyanov and Titlyanova, 2013; Titlyanov et al., 2014, 2015). Cyanobacteria and Rhodophyta prevailed in the upper intertidal zone, while Rhodophyta and Chlorophyta were the most abundant in the middle and lower 
intertidal zones (Titlyanov et al., 2014). Rhodophyta dominated the benthic macroalgal community, $54 \%$ in the upper subtidal zone (Titlyanov and Titlyanova, 2013). The number of species in the marine flora has increased by $28 \%$ from 1990 to 2010 with a displacement of slow-growing species likely due to anthropogenic influences and coral bleaching (Titlyanov et al., 2015). The mean coral cover has decreased in the Luhuitou fringing reef from $90 \%$ in the 1960 s to $12 \%$ in 2009 (Zhao et al., 2012), likely owing to a combination of regional anthropogenic impacts and climate change ( $\mathrm{Li}$ et al., 2012).

To the north of the Luhuitou fringing reef, the Sanya River flows into Sanya Bay, with an annual average discharge of $5.86 \mathrm{~m}^{3} \mathrm{~s}^{-1}$ (Wang et al., 2005). The river is fed mainly by southwest monsoons from May to October. There is no dam in the upstream to regulate the river. During our sampling period the Sanya River plume was confined in the northeast of the bay and the coastal reef station CT was outside the influence of the Sanya River plume (Fig. 1) (Wang et al., 2014). Investigations of nutrients, $\mathrm{Chl} a$, and phytoplankton in the bay have been conducted seasonally for several years (Dong et al., 2010; Wu et al., 2011, 2012b, c) and demonstrate that the inner bay is influenced by the discharge of the Sanya River with its relatively high nutrient levels, and the central and outer bay are dominated by oceanic exchange with the South China Sea (Wu et al., 2012a). Nutrients carried by submarine groundwater discharge into Sanya Bay account for at least $79 \%$ of the nutrients into the bay in our sampling period (Wang et al., submitted). The concentrations of nutrients in the saline groundwater near the reef and in the upper stream of the Sanya River estuary during our sampling period were $1.66 \pm 0.53$ and $8.8 \mu \mathrm{M}$ phosphate, $142 \pm 14$ and $36.6 \mu \mathrm{M}$ oxidized nitrogen $\left(\mathrm{NO}_{x}\right.$, including nitrate and nitrite), and $237 \pm 2$ and $271 \mu \mathrm{M}$ silicate, respectively (Wang et al., 2018).

\subsection{Sampling and measurements}

The setup of the sampling platform at the time-series station CT is provided in detail in Wang et al. (2014). Briefly, water was collected using a submersible pump, and depth and salinity were measured with a conductivity-temperature-depth system (Citadel, RDI Co., USA) attached on a buoy. Discrete nutrient and radium samples were taken every $3 \mathrm{~h}$ during $6-$ 13 February 2012, except on 7-8 February when the maximum tidal range of $1.4 \mathrm{~m}$ occurred (Wang et al., 2014), and the samples were collected every $2 \mathrm{~h}$. A mapping cruise was conducted in Sanya Bay during 2-3 February 2012 (Fig. 1) to evaluate the influence of the Sanya River and to constrain the endmember of the offshore water. Nutrient samples for nitrate, nitrite, phosphate, and silicate were collected in Sanya Bay at surface and bottom depths using 5 L Niskin bottles. Temperature and salinity were measured using a multiparameter sonde YSI 6600. The salinity was reported using the Practical Salinity Scale.

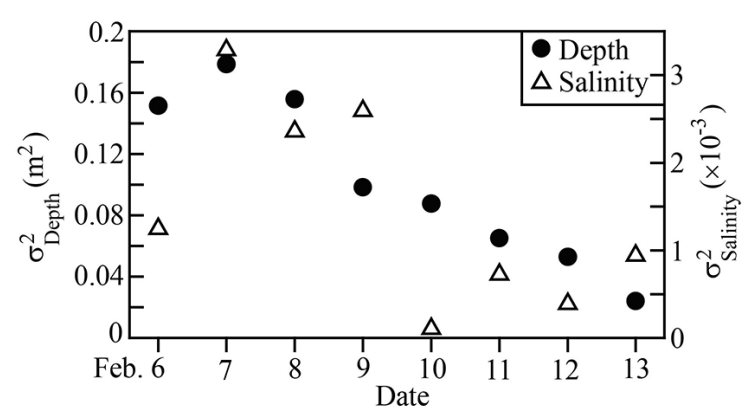

Figure 2. Daily variance of water depth $\left(\sigma_{\text {Depth }}^{2}\right)$ and salinity $\left(\sigma_{\text {Salinity }}^{2}\right)$ at the coastal reef station CT during 6-13 February 2012.

Nutrient samples were filtered with $0.45 \mu \mathrm{m}$ cellulose acetate membranes and poisoned with 1-2\%o chloroform. One filtrate was preserved at $4{ }^{\circ} \mathrm{C}$ for dissolved silicate determination, and one was frozen and kept at $-20^{\circ} \mathrm{C}$ for nitrate, nitrite, and phosphate measurements. In the laboratory, nutrients were measured with an AA3 Auto-Analyzer (Bran-Luebbe, $\mathrm{GmbH}$ ), following the same methods in Han et al. (2012). The analytical precision was better than $1 \%$ for nitrate and nitrite, $2 \%$ for phosphate, and $2.8 \%$ for silicate. The detection limit was $0.04 \mu \mathrm{M}$ for nitrate and nitrite, $0.08 \mu \mathrm{M}$ for phosphate, and $0.16 \mu \mathrm{M}$ for silicate. Blanks were directly set up as baselines during the measurements and subtracted. Radium samples of $30 \mathrm{~L}$ seawater were passed through a $1 \mu \mathrm{m}$ cartridge filter before they were passed through an $\mathrm{MnO}_{2}$-impregnated acrylic fiber ( $\mathrm{Mn}$ fiber) column to extract dissolved radium (Rama and Moore, 1996). The Mn fibers were leached with $1 \mathrm{M}$ solutions of hydroxylamine hydrochloride and $\mathrm{HCl}$ to release ${ }^{226} \mathrm{Ra}$ and ${ }^{228} \mathrm{Ra}$, which were then co-precipitated with $\mathrm{BaSO}_{4}$ and measured in a germanium gamma detector (GCW4022, Canberra) (Moore, 1984) with an error of less than $7 \%$.

\subsection{Linear regression and contour plotting}

To gain insight into factors affecting nutrients from spring to neap tide, linear regressions were conducted between water depth, salinity, and ${ }^{228} \mathrm{Ra}$ activity, between water depth, salinity, and nutrients' concentration, and between biologically contributed nutrients during the spring and neap tide. A significance level of 0.05 was taken. The data were fit using SigmaPlot (Systat Software, San Jose, California, USA; https://systatsoftware.com/). In plotting contours in Sanya Bay, Surfer 11 was utilized with kriging interpolation due to its good linear unbiased prediction of the intermediate values in spatial analysis (Papritz and Stein, 2002). 


\section{Results}

\subsection{Time-series observations of nutrients and radium at the coastal coral reef station}

Time-series observations of salinity, ${ }^{226} \mathrm{Ra}$, and water depth at station CT were reported in Wang et al. (2014), which demonstrated that the water depth at station CT varied from 0.7 to $2.1 \mathrm{~m}$ and the salinity ranged from 33.43 to 33.67 during 6-13 February 2012 (Table S1). The greatest tidal range occurred on 7 February 2012 (Wang et al., 2014), the 16th of the lunar month. To separate neap tide from spring tide days, the daily variance of water depth and salinity were plotted (Fig. 2). The daily variance of a variable was calculated as

$\sigma^{2}=\frac{n \sum x^{2}-\left(\sum x\right)^{2}}{n(n-1)}$,

where $x$ is the average of the variable in a day and $n$ is the number of samples of the variable in that day. A sharp decrease in the variance of salinity occurred on 10 February 2012 and the variance remained low $(<0.001)$ afterwards. Thus, two distinctive groups stood out, with one group in the period of 6-9 February 2012 having greater variance of water depth and salinity and the other in the period of 10-13 February 2012 having less variance. Therefore, we took 6-9 February 2012 as the spring tide period and 10-13 February 2012 as the neap tide period in this work.

The concentration of nutrients varied with different patterns from spring to neap tide (Fig. 3). Nitrite varied from 0.11 to $0.71 \mu \mathrm{M}$ during the spring tide and from 0.12 to $0.74 \mu \mathrm{M}$ in the neap tide, with the maximum diel variation of $0.46 \mu \mathrm{M}$ present during the spring tide (Fig. 3a). The diurnal variation was $0.24-0.46 \mu \mathrm{M}$ during the spring tide and 0.34 $0.45 \mu \mathrm{M}$ in the neap tide. Daily peaks of nitrite usually appeared at high tide from the spring to neap tide. The concentration was positively correlated with water depth $(P<0.05)$ during both the spring and neap tide, but the correlation was less significant during the neap tide (Fig. 4a). Nitrate and phosphate, however, showed an opposite pattern. During the spring tide, nitrate and phosphate were negatively correlated with water depth $(P<0.05)$ (Fig. $4 \mathrm{~b}$ and c). They reached their peak concentrations of 1.91 and $0.22 \mu \mathrm{M}$, respectively, in the late afternoon and their minima of 0.37 and $0.10 \mu \mathrm{M}$, respectively, at night on 7 February 2012 (Fig. 3b and c). The diurnal variation fell in the range of $0.44-1.54 \mu \mathrm{M}$ for nitrate and $0.04-0.12 \mu \mathrm{M}$ for phosphate. During the neap tide, the concentrations varied from 0.27 to $1.32 \mu \mathrm{M}$ for nitrate and 0.084 to $0.18 \mu \mathrm{M}$ for phosphate, with less diurnal variation in the range of $0.35-0.52 \mu \mathrm{M}$ for nitrate and $0.04-0.05 \mu \mathrm{M}$ for phosphate. The correlation with water depth was not significant for both nutrients $(P>0.15)$. Nitrate is the dominant species $(>50 \%)$ of $\mathrm{NO}_{x}$ during the spring-neap tidal period except at 02:00 LT on 12 February 2012 when the concentrations of nitrite and nitrate were almost equal. The $\mathrm{NO}_{x}: \mathrm{P}$ ratio varied from 4.78 to 12.9 in the spring-neap
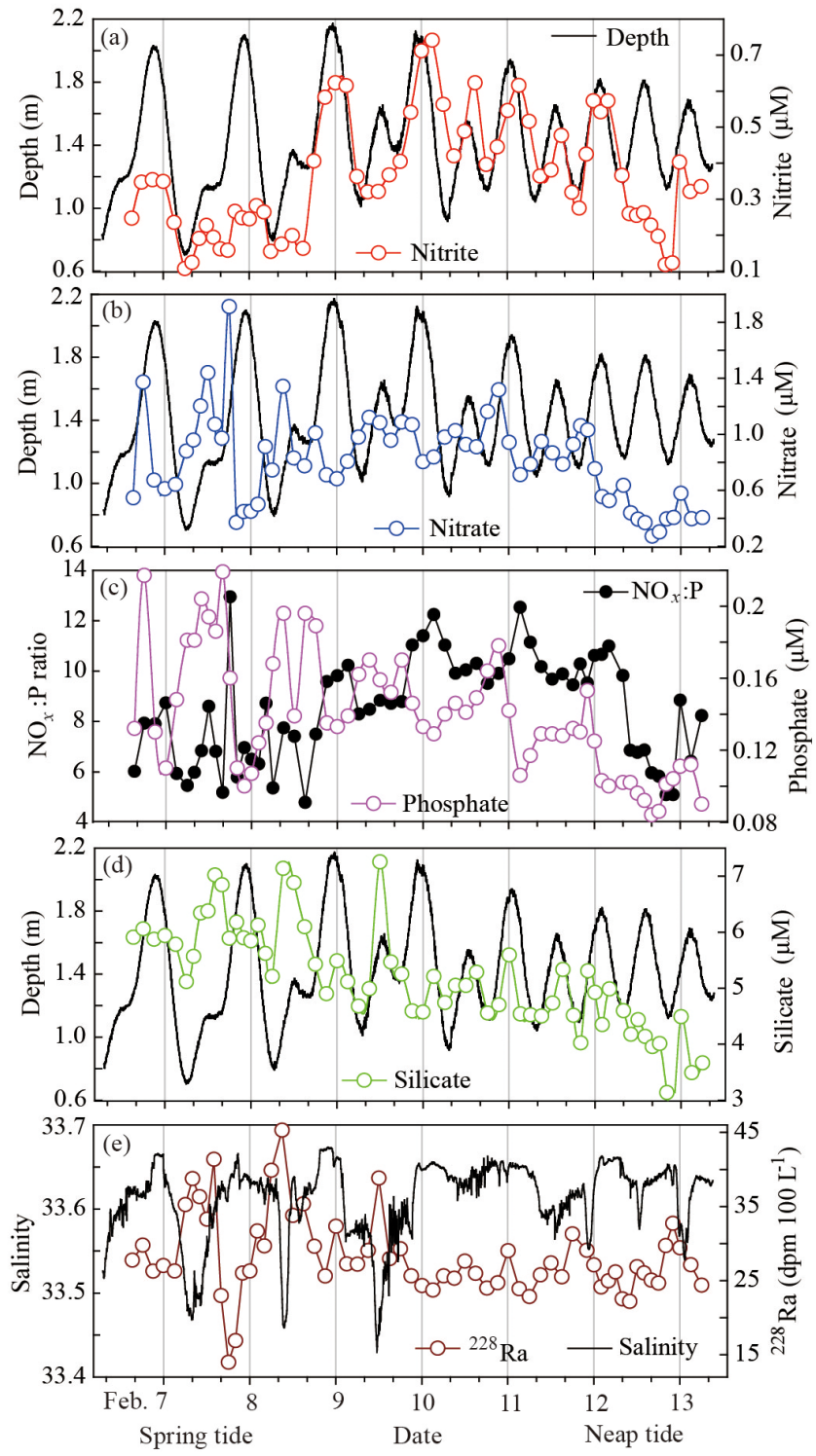

Figure 3. Time-series observations of nutrients and ${ }^{228} \mathrm{Ra}$ at station CT in the Luhuitou reef of Sanya Bay, China, during 613 February 2012. (a) Nitrite, (b) nitrate, (c) phosphate and $\mathrm{NO}_{x}: \mathrm{P}$ ratio, (d) silicate, and (e) ${ }^{228} \mathrm{Ra}$. Lines connecting the symbols are to show trends. Water depth and salinity were reported in Wang et al. (2014).

tide (Fig. 3c). Silicate showed a trend different from either nitrite or nitrate and phosphate (Fig. 3d). It was not significantly correlated with water depth during either spring or neap tide $(P>0.2)$. The concentration of silicate, in general, decreased from spring to neap tide. During the spring tide, the concentration of silicate fell in the range of 4.57$7.25 \mu \mathrm{M}$. The daily peak concentration of silicate appeared almost at the daily lowest salinity. The diurnal variation in silicate was $1.91-2.68 \mu \mathrm{M}$. During the neap tide, however, 

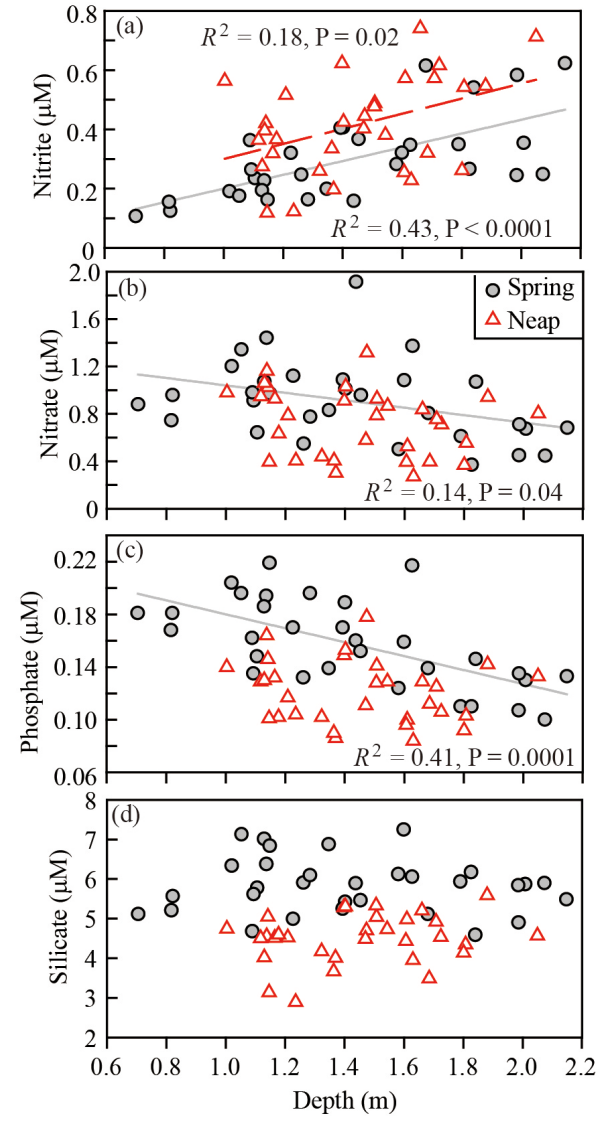

Figure 4. Concentrations of nutrients in the water column against water depth during the spring tide and neap tide at station CT in the Luhuitou reef during 6-13 February 2012. (a) Nitrite, (b) nitrate, (c) phosphate, and (d) silicate.

silicate ranged from 2.89 to $5.59 \mu \mathrm{M}$ and showed less diurnal variability, $1.44-2.09 \mu \mathrm{M}$.

The diurnal variation in the activity of ${ }^{228} \mathrm{Ra}$ at sta-

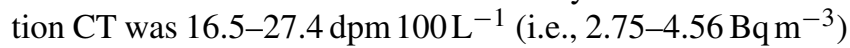
during the spring tide, the maximum of which appeared on 7 February, and 5.31-10.6 dpm $100 \mathrm{~L}^{-1}$ around the neap tide (Fig. 3e). The maximum ${ }^{228} \mathrm{Ra}, 45.3 \mathrm{dpm} 100 \mathrm{~L}^{-1}$, appeared at low tide on 8 February during the spring tide and the minimum, $14.0 \mathrm{dpm} 100 \mathrm{~L}^{-1}$, appeared during the flood tide of the spring tide on 7 February. The activity of ${ }^{228} \mathrm{Ra}$ was significantly correlated with water depth in the spring-neap tidal period $(P=0.002)$ (Fig. 5a). This pattern reflected the variation in the groundwater discharge induced by tidal pumping in this coral reef system (Wang et al., 2014), which is also observed in other coastal regions (Burnett and Dulaiova, 2003; Santos et al., 2010).

\subsection{Distributions of nutrients in Sanya Bay}

In Sanya Bay the highest concentration of nutrients appeared near the Sanya River estuary, and the concentration, in gen- eral, decreased from the northeast coast, where the influence of the Sanya River plume is apparent in winter (Wang et al., 2014), to the south and west, where the South China Sea water intrudes (Fig. 6). At stations far offshore (stations J4-5 and W3-4), the concentrations of nitrite, nitrate, and phosphate were all below the detection limit and the concentration of silicate was about $4.00 \mu \mathrm{M}$. At other stations, the concentration of all the nutrients remained low, but was nonetheless detectable. For example, the maximum concentrations of only $0.43 \mu \mathrm{M}$ for nitrite, $0.70 \mu \mathrm{M}$ for nitrate, $0.18 \mu \mathrm{M}$ for phosphate, and $7.92 \mu \mathrm{M}$ for silicate were recorded at station P1, the station closest to the Sanya River estuary. The small islands in Sanya Bay did not show apparent influence on the nutrients in the bay since nutrients were below their detection limits or remained low around these islands (Fig. 6). The water depth at these mapping stations was no less than $5 \mathrm{~m}$ and the concentration of nutrients at the bottom depth differed little from that at the surface at most of these offshore stations (Table 1). This vertical distribution confirms that the water in Sanya Bay is relatively homogenous in February (Wang et al., 2014). The $\mathrm{NO}_{x}$ : $\mathrm{P}$ ratio was less than 7 in Sanya Bay, except at stations $\mathrm{P} 2$ and $\mathrm{L} 6$ where the $\mathrm{NO}_{x}: \mathrm{P}$ ratio was around 9 .

\section{Discussion}

\subsection{What affects tidal variation in nutrients at the reef station CT?}

The time-series observation of salinity at station CT suggests that more freshwater input into the reef system occurred during the ebb flow of the spring tide as inferred from lower salinity than during that of the neap tide (Wang et al., 2014). The distribution of salinity in Sanya Bay demonstrated that the surface salinity was slightly lower in the northeast off the Sanya River mouth than in southern Sanya Bay (Fig. 1a). At stations P1 and P2 the surface salinity was less than 33.70 , while at stations around station CT, i.e., stations L1, L2, L3, and $\mathrm{P} 3$, the surface salinity was greater than 33.80 (Table 1). The vertical profiles of salinity at these stations also showed a similar difference, with salinity below 33.80 throughout the water column at river-influenced stations (Fig. 1b). This indicates that the Sanya River plume affected the northeast of the bay with little impact on station CT and that the only source of freshwater at station CT in February would be groundwater discharge (Wang et al., 2014) since in the two weeks before our sampling and during our sampling period there were no rainfall and consequent surface runoff in this area. The coincidence of the daily minimum salinity with the highest activity of ${ }^{228}$ Ra during the ebb flow of the spring tide (Fig. 3e) and the significant correlation between the activity of ${ }^{228} \mathrm{Ra}$ and salinity during the spring-neap tidal period $(P<0.0001)$ (Fig. 5b) confirms that the tidally driven groundwater discharge occurred at the coral reef station CT. Greater ground- 

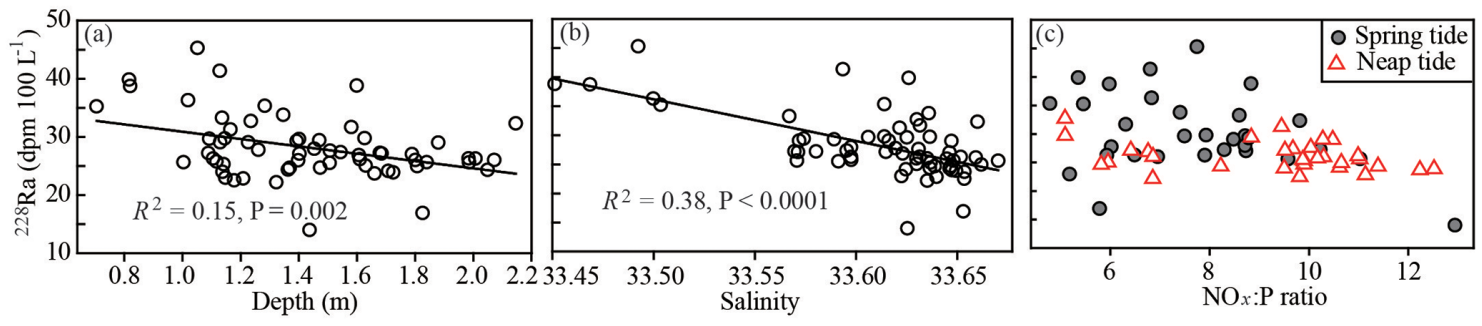

Figure 5. The activity of ${ }^{228} \mathrm{Ra}$ against (a) water depth, (b) salinity, and (c) the $\mathrm{NO}_{x}: \mathrm{P}$ ratio in the water column at station CT during 6-13 February 2012.
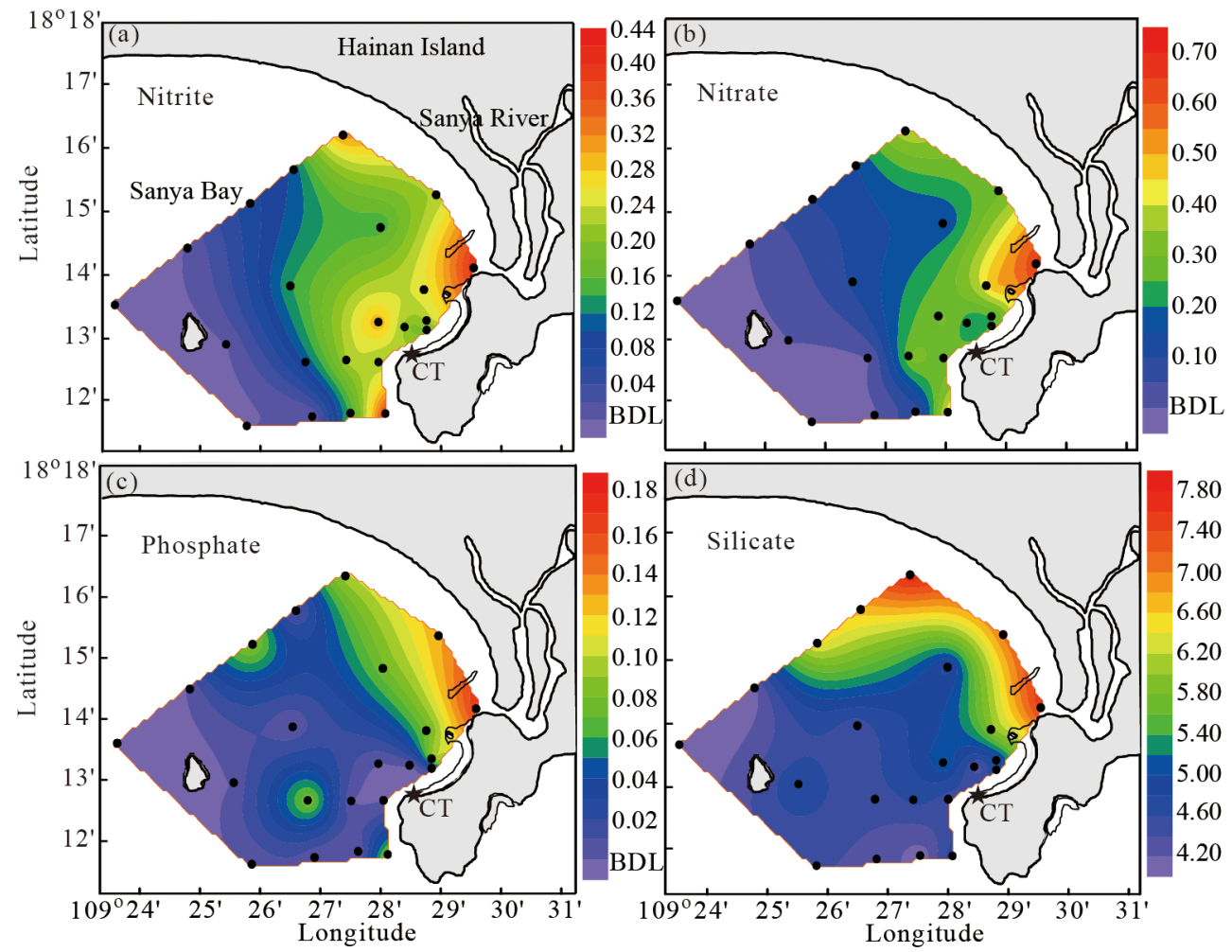

Figure 6. Surface distributions of nutrients in Sanya Bay in February 2012. (a) Nitrite, (b) nitrate, (c) phosphate, and (d) silicate. The units are in $\mu \mathrm{M}$. BDL refers to below the detection limit, which is $0.04 \mu \mathrm{M}$ for nitrate and nitrite and $0.08 \mu \mathrm{M}$ for phosphate.

water discharge appeared during the ebb flow in the spring tide than in the neap tide as indicated by the higher activity of ${ }^{228} \mathrm{Ra}$, bringing more groundwater into the reef system.

Under the influence of tidally driven groundwater discharge, variation in nitrite, nitrate, phosphate, and silicate during the spring tide followed a tidal pattern. Inferred from the significant correlation between nutrients and water depth during the spring tide (Fig. 4), the groundwater discharge was characterized by higher nitrate and phosphate and lower nitrite than the offshore seawater. Since nitrate dominated $\mathrm{NO}_{x}$ during the time-series observation (Fig. 3), groundwater discharge was characterized by higher $\mathrm{NO}_{x}$ and phosphate than the offshore seawater. Because groundwater discharge was greater at low tide than at high tide due to its tidal pump- ing feature, higher $\mathrm{NO}_{x}$ and phosphate would appear at low tide. From Fig. 4, the daily maximum concentration of $\mathrm{NO}_{x}$, phosphate, and silicate appeared in the daytime at relatively low tide, while the minimum appeared mostly at night at high tide, indicating the mixing of tidally driven groundwater and offshore seawater. During the neap tide, however, $\mathrm{NO}_{x}$ and phosphate showed less diurnal variation. The daily maximum concentration of $\mathrm{NO}_{x}$ and phosphate appeared around midnight, when a flood tide appeared. This pattern of daily maximum in a flood tide at night reflected dominance of biological processes because in a flood tide there were fewer groundwater-associated nutrients and nutrients were released the most at night by biological processes. This pattern is consistent with the time-series observation of dissolved oxygen 
Table 1. Sampling stations and data collected in Sanya Bay in February 2012.

\begin{tabular}{|c|c|c|c|c|c|c|c|c|c|c|}
\hline Station & $\begin{array}{l}\text { Latitude } \\
\left({ }^{\circ} \mathrm{N}\right)\end{array}$ & $\begin{array}{l}\text { Longitude } \\
\left({ }^{\circ} \mathrm{E}\right)\end{array}$ & $\begin{array}{r}\text { Bottom } \\
\text { depth }(m)\end{array}$ & $\begin{array}{r}\text { Sample } \\
\text { depth }(m)\end{array}$ & $\begin{array}{r}\text { Temperature } \\
\left({ }^{\circ} \mathrm{C}\right)\end{array}$ & Salinity & $\begin{array}{c}\mathrm{NO}_{2}^{-} \\
(\mu \mathrm{M})\end{array}$ & $\begin{array}{l}\mathrm{NO}_{3}^{-} \\
(\mu \mathrm{M})\end{array}$ & $\begin{array}{c}\mathrm{PO}_{4}^{3-} \\
(\mu \mathrm{M})\end{array}$ & $\begin{array}{r}\mathrm{SiO}_{3}^{2-} \\
(\mu \mathrm{M})\end{array}$ \\
\hline $\mathrm{J} 1$ & 18.2718 & 109.4565 & 8 & $\begin{array}{l}0.5 \\
6.5\end{array}$ & $\begin{array}{l}22.80 \\
22.74\end{array}$ & $\begin{array}{l}33.60 \\
33.60\end{array}$ & $\begin{array}{l}0.328 \\
0.298\end{array}$ & $\begin{array}{l}0.410 \\
0.343\end{array}$ & $\begin{array}{l}0.104 \\
0.098\end{array}$ & $\begin{array}{l}7.916 \\
7.485\end{array}$ \\
\hline $\mathrm{J} 2$ & 18.2623 & 109.4423 & 9 & $\begin{array}{l}0.5 \\
8.0\end{array}$ & $\begin{array}{l}22.66 \\
22.64\end{array}$ & $\begin{array}{l}33.62 \\
33.63\end{array}$ & $\begin{array}{l}0.103 \\
0.124\end{array}$ & $\begin{array}{l}0.149 \\
0.162\end{array}$ & $\begin{array}{l}\text { BDL } \\
\text { BDL }\end{array}$ & $\begin{array}{l}6.708 \\
6.531\end{array}$ \\
\hline $\mathrm{J} 3$ & 18.2531 & 109.4298 & 12 & $\begin{array}{r}0.5 \\
11.0\end{array}$ & $\begin{array}{l}22.70 \\
22.69\end{array}$ & $\begin{array}{l}33.64 \\
33.65\end{array}$ & $\begin{array}{l}0.073 \\
0.104\end{array}$ & $\begin{array}{l}0.104 \\
0.067\end{array}$ & $\begin{array}{l}0.090 \\
0.108\end{array}$ & $\begin{array}{l}6.472 \\
6.318\end{array}$ \\
\hline $\mathrm{J} 4$ & 18.2409 & 109.4118 & 11 & $\begin{array}{r}0.5 \\
12.4\end{array}$ & $\begin{array}{l}22.81 \\
22.81\end{array}$ & $\begin{array}{l}33.70 \\
33.70\end{array}$ & $\begin{array}{l}\text { BDL } \\
\text { BDL }\end{array}$ & $\begin{array}{l}\text { BDL } \\
\text { BDL }\end{array}$ & $\begin{array}{l}\text { BDL } \\
\text { BDL }\end{array}$ & $\begin{array}{l}4.069 \\
4.095\end{array}$ \\
\hline J5 & 18.2261 & 109.3909 & 15 & $\begin{array}{r}0.5 \\
14.0\end{array}$ & $\begin{array}{l}22.90 \\
22.88\end{array}$ & $\begin{array}{l}33.70 \\
33.74\end{array}$ & $\begin{array}{l}\text { BDL } \\
\text { BDL }\end{array}$ & $\begin{array}{l}\text { BDL } \\
\text { BDL }\end{array}$ & $\begin{array}{l}\text { BDL } \\
\text { BDL }\end{array}$ & $\begin{array}{l}4.058 \\
4.126\end{array}$ \\
\hline W4 & 18.2154 & 109.4244 & 17 & $\begin{array}{r}0.5 \\
17.5\end{array}$ & $\begin{array}{l}22.90 \\
22.73\end{array}$ & $\begin{array}{l}33.70 \\
33.75\end{array}$ & $\begin{array}{l}\text { BDL } \\
\text { BDL }\end{array}$ & $\begin{array}{l}\text { BDL } \\
\text { BDL }\end{array}$ & $\begin{array}{l}\text { BDL } \\
\text { BDL }\end{array}$ & $\begin{array}{l}4.768 \\
4.760\end{array}$ \\
\hline W3 & 18.2306 & 109.4413 & 16 & $\begin{array}{r}0.5 \\
16.0\end{array}$ & $\begin{array}{l}22.97 \\
23.40\end{array}$ & $\begin{array}{l}33.89 \\
33.60\end{array}$ & $\begin{array}{l}0.136 \\
0.063\end{array}$ & $\begin{array}{l}0.112 \\
0.098\end{array}$ & $\begin{array}{l}\text { BDL } \\
\text { BDL }\end{array}$ & $\begin{array}{l}4.476 \\
5.188\end{array}$ \\
\hline W2 & 18.2466 & 109.4672 & 12 & $\begin{array}{l}0.5 \\
9.5\end{array}$ & $\begin{array}{l}22.93 \\
22.76\end{array}$ & $\begin{array}{l}33.72 \\
33.73\end{array}$ & $\begin{array}{l}0.147 \\
0.075\end{array}$ & $\begin{array}{l}0.158 \\
0.127\end{array}$ & $\begin{array}{c}0.081 \\
\text { BDL }\end{array}$ & $\begin{array}{l}4.724 \\
5.179\end{array}$ \\
\hline W1 & 18.2555 & 109.4832 & 5 & $\begin{array}{l}0.5 \\
3.0\end{array}$ & $\begin{array}{l}23.12 \\
22.92\end{array}$ & $\begin{array}{l}33.70 \\
33.73\end{array}$ & $\begin{array}{l}0.228 \\
0.228\end{array}$ & $\begin{array}{l}0.299 \\
0.234\end{array}$ & $\begin{array}{l}0.131 \\
0.102\end{array}$ & $\begin{array}{l}7.136 \\
6.317\end{array}$ \\
\hline P3 & 18.2213 & 109.4660 & 16 & $\begin{array}{r}0.5 \\
16.0\end{array}$ & $\begin{array}{l}22.75 \\
22.87\end{array}$ & $\begin{array}{l}33.84 \\
33.76\end{array}$ & $\begin{array}{l}0.300 \\
0.132\end{array}$ & $\begin{array}{l}0.309 \\
0.144\end{array}$ & $\begin{array}{l}\text { BDL } \\
\text { BDL }\end{array}$ & $\begin{array}{l}5.172 \\
4.655\end{array}$ \\
\hline $\mathrm{P} 2$ & 18.2296 & 109.4797 & 11 & $\begin{array}{r}0.5 \\
11.0\end{array}$ & $\begin{array}{l}23.01 \\
22.90\end{array}$ & $\begin{array}{l}33.67 \\
33.77\end{array}$ & $\begin{array}{l}0.262 \\
0.206\end{array}$ & $\begin{array}{l}0.496 \\
0.204\end{array}$ & $\begin{array}{c}0.082 \\
\text { BDL }\end{array}$ & $\begin{array}{l}6.035 \\
4.569\end{array}$ \\
\hline P1 & 18.2355 & 109.4940 & 5 & $\begin{array}{l}0.5 \\
2.8\end{array}$ & $\begin{array}{l}22.98 \\
22.97\end{array}$ & $\begin{array}{l}33.62 \\
33.64\end{array}$ & $\begin{array}{l}0.426 \\
0.350\end{array}$ & $\begin{array}{l}0.699 \\
0.525\end{array}$ & $\begin{array}{l}0.178 \\
0.157\end{array}$ & $\begin{array}{l}7.726 \\
7.671\end{array}$ \\
\hline P4 & 18.2105 & 109.4464 & 12 & $\begin{array}{r}0.5 \\
19.0\end{array}$ & $\begin{array}{l}22.71 \\
22.67\end{array}$ & $\begin{array}{l}33.89 \\
33.89\end{array}$ & $\begin{array}{l}0.108 \\
0.200\end{array}$ & $\begin{array}{l}0.002 \\
0.013\end{array}$ & $\begin{array}{l}0.081 \\
0.130\end{array}$ & $\begin{array}{l}4.519 \\
4.935\end{array}$ \\
\hline P5 & 18.1931 & 109.4296 & 26 & $\begin{array}{r}0.5 \\
26.0\end{array}$ & $\begin{array}{l}22.69 \\
22.74\end{array}$ & $\begin{array}{l}33.81 \\
33.87\end{array}$ & $\begin{array}{r}\text { BDL } \\
0.054\end{array}$ & $\begin{array}{r}\text { BDL } \\
0.076\end{array}$ & $\begin{array}{l}\text { BDL } \\
\text { BDL }\end{array}$ & $\begin{array}{l}4.428 \\
4.522\end{array}$ \\
\hline L8 & 18.1964 & 109.4476 & 25 & $\begin{array}{r}0.5 \\
25.5\end{array}$ & $\begin{array}{l}22.78 \\
22.75\end{array}$ & $\begin{array}{l}33.88 \\
33.88\end{array}$ & $\begin{array}{r}\text { BDL } \\
0.191\end{array}$ & $\begin{array}{r}\text { BDL } \\
0.005\end{array}$ & $\begin{array}{r}\text { BDL } \\
0.082\end{array}$ & $\begin{array}{l}4.282 \\
4.528\end{array}$ \\
\hline L7 & 18.1966 & 109.4601 & 32 & $\begin{array}{r}0.5 \\
30.7\end{array}$ & $\begin{array}{l}22.83 \\
22.78\end{array}$ & $\begin{array}{l}33.86 \\
33.87\end{array}$ & $\begin{array}{l}0.171 \\
0.077\end{array}$ & $\begin{array}{l}0.092 \\
0.081\end{array}$ & $\begin{array}{l}\text { BDL } \\
\text { BDL }\end{array}$ & $\begin{array}{l}4.093 \\
4.400\end{array}$ \\
\hline L6 & 18.1965 & 109.4694 & 23 & $\begin{array}{r}0.5 \\
27.0\end{array}$ & $\begin{array}{l}22.79 \\
22.77\end{array}$ & $\begin{array}{l}33.82 \\
33.87\end{array}$ & $\begin{array}{l}0.420 \\
0.405\end{array}$ & $\begin{array}{l}0.516 \\
0.431\end{array}$ & $\begin{array}{l}0.097 \\
0.112\end{array}$ & $\begin{array}{l}4.859 \\
4.839\end{array}$ \\
\hline L5 & 18.2111 & 109.4582 & 21 & $\begin{array}{r}0.5 \\
18.0\end{array}$ & $\begin{array}{l}22.74 \\
22.79\end{array}$ & $\begin{array}{l}33.85 \\
33.86\end{array}$ & $\begin{array}{l}0.231 \\
0.355\end{array}$ & $\begin{array}{l}0.326 \\
0.392\end{array}$ & $\begin{array}{r}\text { BDL } \\
0.097\end{array}$ & $\begin{array}{l}4.643 \\
4.480\end{array}$ \\
\hline L4 & 18.2105 & 109.4674 & 20 & $\begin{array}{r}0.5 \\
21.0\end{array}$ & $\begin{array}{l}22.76 \\
22.77\end{array}$ & $\begin{array}{l}33.85 \\
33.87\end{array}$ & $\begin{array}{l}0.219 \\
0.285\end{array}$ & $\begin{array}{l}0.248 \\
0.309\end{array}$ & $\begin{array}{l}\text { BDL } \\
\text { BDL }\end{array}$ & $\begin{array}{l}4.484 \\
4.645\end{array}$ \\
\hline L3 & 18.2201 & 109.4749 & 12 & $\begin{array}{r}0.5 \\
12.8\end{array}$ & $\begin{array}{l}22.79 \\
22.79\end{array}$ & $\begin{array}{l}33.84 \\
33.86\end{array}$ & $\begin{array}{l}0.194 \\
0.202\end{array}$ & $\begin{array}{l}0.193 \\
0.183\end{array}$ & $\begin{array}{l}\text { BDL } \\
\text { BDL }\end{array}$ & $\begin{array}{l}4.315 \\
4.444\end{array}$ \\
\hline L2 & 18.2193 & 109.4812 & 11 & $\begin{array}{r}0.5 \\
11.0\end{array}$ & $\begin{array}{l}22.81 \\
22.80\end{array}$ & $\begin{array}{l}33.85 \\
33.86\end{array}$ & $\begin{array}{l}0.192 \\
0.195\end{array}$ & $\begin{array}{l}0.309 \\
0.218\end{array}$ & $\begin{array}{l}\text { BDL } \\
\text { BDL }\end{array}$ & $\begin{array}{l}5.006 \\
4.639\end{array}$ \\
\hline L1 & 18.2219 & 109.4812 & 11 & $\begin{array}{r}0.5 \\
11.0\end{array}$ & $\begin{array}{l}22.76 \\
22.81\end{array}$ & $\begin{array}{l}33.84 \\
33.87\end{array}$ & $\begin{array}{l}0.244 \\
0.353\end{array}$ & $\begin{array}{l}0.253 \\
0.235\end{array}$ & $\begin{array}{l}0.101 \\
0.107\end{array}$ & $\begin{array}{l}4.887 \\
5.252\end{array}$ \\
\hline
\end{tabular}

Note that BDL refers to below the detection limit. 
at this site (Wang et al., 2014). The daily minimum appeared for $\mathrm{NO}_{x}$ and phosphate in the afternoon or between midnight and dawn at high tide, reflecting the dominance of nutrientdepleted offshore seawater. Adsorption/desorption from particles might be a factor influencing the phosphate concentration, as proposed for estuaries (e.g., Froelich et al., 1982; van der Zee et al., 2007). At the reef station the salinity was close to the seawater $(>33)$ and the water was clear (the total suspended matter was low, about $15 \mathrm{mgL}^{-1}$ ), which makes adsorption/desorption negligible. The clear water, as well as low wave energy in the reef in winter (Zhang, 2001), also limits the possibility of sediment resuspension being a source of radium and nutrients.

Under the controls of tidally driven groundwater discharge and biological processes, the composition of nutrients in the reef system also differed from the spring tide to the neap tide. During the spring tide when groundwater discharge played a predominant role in regulating the concentration of nutrients in the reef system, the concentration of $\mathrm{NO}_{x}$ was positively correlated with the concentration of phosphate, with a regression slope of 5.43 and $R^{2}$ of 0.27 (Fig. 7a). The concentration of silicate was not significantly correlated with the concentration of $\mathrm{NO}_{x}$ (Fig. 7b). During the neap tide when groundwater discharge was less prominent, the correlation between the concentrations of $\mathrm{NO}_{x}$ and phosphate was more significant, with a regression slope of 14.2 and $R^{2}$ of 0.76 . The $\mathrm{NO}_{x}: \mathrm{P}$ ratio was closer to the Redfield ratio than during the spring tide. The concentration of silicate showed significant correlation with the concentration of $\mathrm{NO}_{x}$ in the water column, with a regression slope of 1.24 and $R^{2}$ of 0.58. Diatoms dominate the phytoplankton community in Sanya Bay (Zhou et al., 2009). The elemental ratio of Si : $\mathrm{N}$ is $0.80 \pm 0.35$ for nanoplankton and $1.20 \pm 0.37$ for net plankton (Brzezinski, 1985). The similarity of the composition of silicate and $\mathrm{NO}_{x}$ in the water column to the elemental ratio of diatoms implies a biological control. Unfortunately, no information is available on particular reef primary producers and sponges that may take up/release silicate in this reef system to further the discussion. The activity of ${ }^{228} \mathrm{Ra}$, however, was not significantly correlated with the $\mathrm{NO}_{x}: \mathrm{P}$ ratio in the water column from spring to neap tide $(P>0.05)$ (Fig. $5 \mathrm{c})$, indicating that the composition of nutrients in the water column was not predominantly controlled by groundwater discharge. Therefore, we propose that biological processes predominantly controlled the composition of nutrients in the reef system but that there was less of an impact in the spring tide due to groundwater discharge.

\subsection{The generation and consumption of $\mathrm{NO}_{x}$ and phosphate at the reef station $\mathrm{CT}$}

$\mathrm{N}$ and $\mathrm{P}$ are the general limiting nutrients for the abundance of phytoplankton in coastal ecosystems (Jickells et al., 1998). To quantify the contribution of biological processes to the variation in the $\mathrm{NO}_{x}$ and phosphate at station $\mathrm{CT}$, a closer look was taken at the behaviors of nitrite, nitrate, and phosphate with salinity during the falling and rising phases on February 7 , the day with the greatest tidal range in the spring tide period. Figure 8 shows that these nutrients behaved differently during the two phases. During the ebb flow, with a fast falling speed as indicated by the sharp slope of water depth (Fig. 3), nitrite, nitrate, and phosphate behaved conservatively; i.e., their concentrations were significantly correlated with salinity $(P<0.05)$. Nitrite was positively correlated with salinity $\left(R^{2}=0.94\right)$, while nitrate and phosphate were negatively correlated with salinity $\left(R^{2}=0.91\right.$ and 0.90 , respectively) (Fig. 8). These conservative behaviors indicated mixing between the groundwater discharge and the offshore seawater. During the flood tide, with a relatively slow speed as indicated by a smaller slope of water depth (Fig. 3), however, nitrite showed an apparent removal signal relative to the conservative mixing line while additions of nitrate and phosphate appeared. This consumption of nitrite and generation of nitrate and phosphate were due to biological processes in this period. Based on the conservative mixing lines shown in Fig. 8, we could estimate nitrite, nitrate, and phosphate owing to mixing of the offshore seawater and groundwater discharge using the salinity measured at station CT $\left(S_{\mathrm{CT}}\right)$, designated as $\mathrm{NO}_{2 \text { mix }}, \mathrm{NO}_{3 \text { mix }}$, and $\mathrm{P}_{\text {mix }}$ :

$$
\begin{aligned}
& \mathrm{NO}_{2 \text { mix }}=(1.37 \pm 0.21) \cdot S_{\mathrm{CT}}-(45.75 \pm 6.88), \\
& \mathrm{NO}_{3 \text { mix }}=(-1.78 \pm 0.32) \cdot S_{\mathrm{CT}}+(60.50 \pm 10.82), \\
& \mathrm{P}_{\text {mix }}=(-0.36 \pm 0.07) \cdot S_{\mathrm{CT}}+(12.12 \pm 2.27) .
\end{aligned}
$$

Two assumptions were made before setting up these equations: (a) there was no other water mass flowing into the reef system besides offshore seawater and groundwater, and (b) mixing of offshore seawater and groundwater from spring to neap tide followed the relation derived from data on the day with the greatest tidal range. The differences between the measured concentrations of nutrients and the nutrient concentrations resulting from mixing represented nutrients contributed by biological processes, designated as $\Delta \mathrm{NO}_{2 \text { bio }}$, $\Delta \mathrm{NO}_{3 \text { bio }}$ and $\Delta \mathrm{P}_{\text {bio }}$ :

$$
\begin{aligned}
& \Delta \mathrm{NO}_{2 \text { bio }}=\mathrm{NO}_{2 \mathrm{CT}}-\mathrm{NO}_{2 \text { mix }}, \\
& \Delta \mathrm{NO}_{3 \text { bio }}=\mathrm{NO}_{3 \mathrm{CT}}-\mathrm{NO}_{3 \text { mix }}, \\
& \Delta \mathrm{P}_{\text {bio }}=\mathrm{P}_{\mathrm{CT}}-\mathrm{P}_{\text {mix }},
\end{aligned}
$$

where the subscript "CT" represents the measured value at station $\mathrm{CT}$. The oxidized nitrogen contributed by biological processes, $\Delta \mathrm{NO}_{x \text { bio }}$, is the sum of $\Delta \mathrm{NO}_{2 \text { bio }}$ and $\Delta \mathrm{NO}_{3 \text { bio. }}$. Positive values represent regeneration and release of nutrients in the water column, and negative values reflect uptake of nutrients by marine flora (including phytoplankton and benthic flora in this system). Benthic release due to remineralization of organic matter contributes to the positive values.

The nutrients contributed by biological processes showed the greatest diurnal variation in nitrate and phosphate on 7 February 2012, which is in the spring tide, while the 

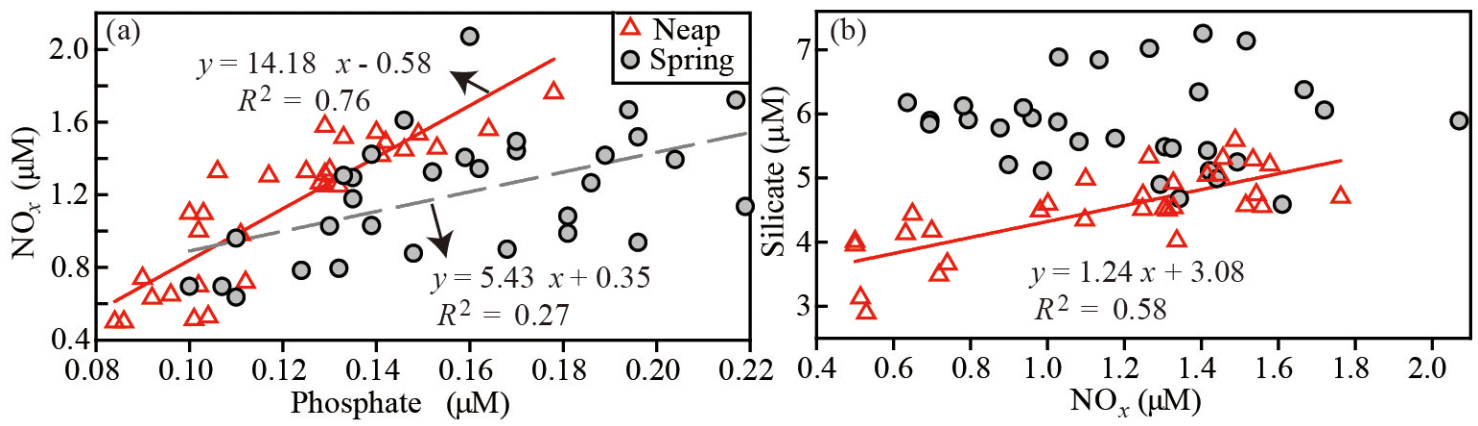

Figure 7. Concentrations of (a) $\mathrm{NO}_{x}$ against phosphate and (b) silicate against $\mathrm{NO}_{x}$ in the water column during the spring tide and neap tide at station CT during 6-13 February 2012.
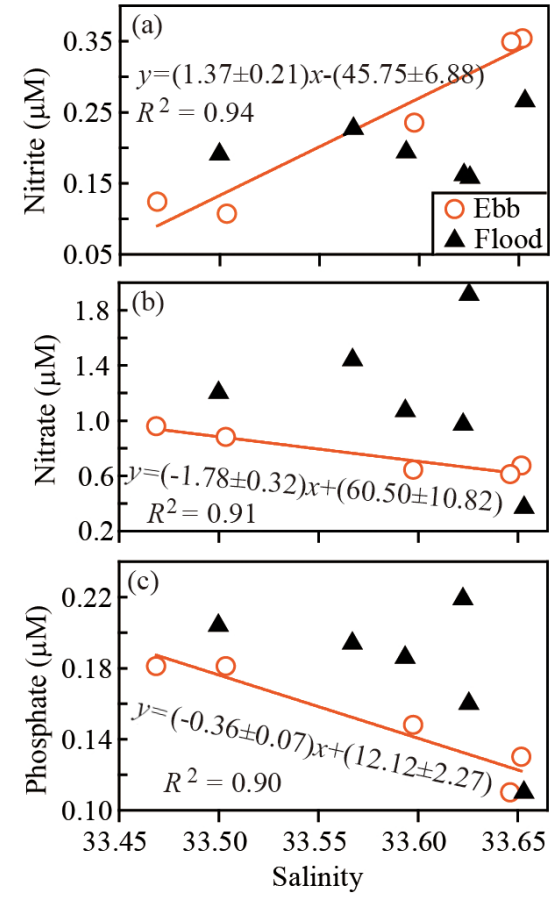

Figure 8. Behaviors of nutrients with salinity during the ebb flow and flood tide of the spring tide at station CT. (a) Nitrite, (b) nitrate, and (c) phosphate.

maximum of biologically contributed nitrite appeared on 12 February 2012, which is in the neap tide (Fig. 9). Nitrite contributed by biological processes ranged from -0.15 to $0.39 \mu \mathrm{M}$ during the spring tide and from -0.20 to $0.40 \mu \mathrm{M}$ during the neap tide (Fig. 9a). From 18:00 on 8 February to $18: 00$ on 11 February 2012 , biologically contributed nitrite was positive throughout the period, indicating production of nitrite. For nitrate it was produced throughout the period from 04:00 on 8 February to midnight on 11 February 2012. During the spring tide biologically contributed nitrate varied from -0.24 to $1.25 \mu \mathrm{M}$ and during the neap tide it fell in the range of -0.38 to $0.70 \mu \mathrm{M}$. Net $\mathrm{NO}_{x}$ production oc-

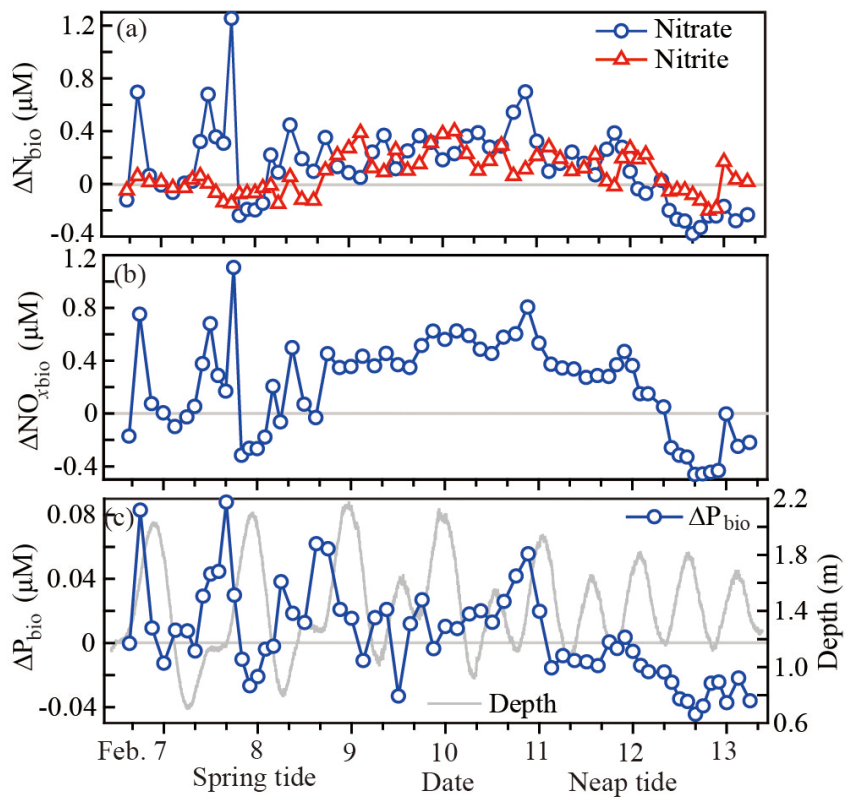

Figure 9. Variations of nutrients contributed by biological processes in a spring-neap tide during 6-13 February 2012 at the coastal reef station CT. (a) Nitrite and nitrate, (b) $\mathrm{NO}_{x}$, and (c) phosphate (P). Water depth was reported in Wang et al. (2014).

curred from 18:00 on 8 February to 08:00 on 12 February 2012 and $\Delta \mathrm{NO}_{x \text { bio }}$ was negative afterwards on 12-13 February 2012, indicating net consumption (Fig. 9b). The biological contribution of phosphate had greater diurnal variation during the spring tide than during the neap tide (Fig. 9c). The greatest diel variation during the spring tide in $\Delta \mathrm{P}_{\text {bio }}$ appeared on 7 February 2012 when $\Delta \mathrm{P}_{\text {bio }}$ varied from -0.027 to $0.088 \mu \mathrm{M}$, while during the neap tide the greatest variation occurred on 10 February 2012 when $\Delta \mathrm{P}_{\text {bio }}$ ranged from 0.009 to $0.056 \mu \mathrm{M}$. Net phosphate consumption occurred throughout the period of 12-13 February 2012.

The relationship between $\Delta \mathrm{NO}_{x \text { bio }}$ and $\Delta \mathrm{P}_{\text {bio }}$ during the spring tide differed from that during the neap tide. Note that $\mathrm{NO}_{x}$ is not equivalent to dissolved inorganic nitrogen (DIN). 


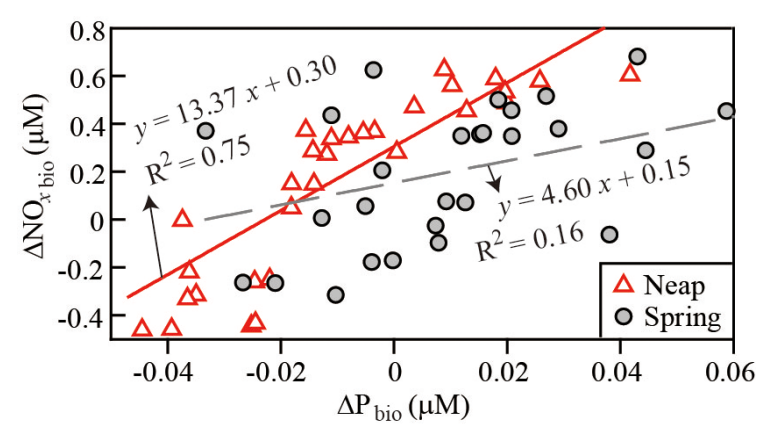

Figure 10. Relationship between biologically contributed $\mathrm{NO}_{x}$ and phosphate during the spring tide and neap tide at station $\mathrm{CT}$ in the Luhuitou fringing reef in 6-13 February 2012.

Ammonium data are not available in this study for us to discuss the relationship between DIN and phosphate, which limited our discussion to $\mathrm{NO}_{x}$ and makes the picture of microbial processes that control dissolved inorganic nitrogen in the coral reef system incomplete. However, tidal variation in ammonium is expected at this site and may have been related to the change in the relationship between $\Delta \mathrm{NO}_{x \text { bio }}$ and $\Delta \mathrm{P}_{\text {bio }}$. During the spring tide there was significant correlation between $\Delta \mathrm{NO}_{x \text { bio }}$ and $\Delta \mathrm{P}_{\text {bio }}$, with a regression slope of 4.60 and $R^{2}$ of 0.16 (Fig. 10). During the neap tide, however, the correlation was much more significant with a regression slope of 13.4 and $R^{2}$ of 0.75 . The regression slope of the regression between biologically contributed $\mathrm{NO}_{x \text { bio }}$ and phosphate was similar to that of the significant regression between $\mathrm{NO}_{x \text { bio }}$ and phosphate in the water column, which was 5.43 during the spring tide and 14.18 during the neap tide. This similarity indicates that the composition of nutrients in the water column was closely related with biological processes during both tidal periods, but the biological effect appeared to be less evident during the spring tide as inferred from the less significant correlations. The net release of nutrients during the neap tide with a very Redfield-like ratio suggests that the net nutrient fluxes in this system were likely to be dominated by the uptake and remineralization of plankton/oceanic organic particles by benthic filter feeders as observed in other reefs (e.g., Ayukai, 1995; Ribes et al., 2005; Southwell et al., 2008; Genin et al., 2009; Monismith et al., 2010). The net uptake of nitrate and phosphate was mainly done by reef primary producers. Thus, the composition of nutrients in the water column seemed to be directly related with biological contributions from the spring to neap tide. The biological influence was less dominant during the spring tide, most likely due to groundwater discharge. This confirms our proposal that biological processes predominantly controlled the composition of nutrients in the reef system but that there was less of an impact due to groundwater discharge.

Successive uptake rates of $\mathrm{NO}_{x}$ were approximated by the depth integration of the biologically contributed $\mathrm{NO}_{x}$ divided by the sampling time interval from the spring to neap tide.

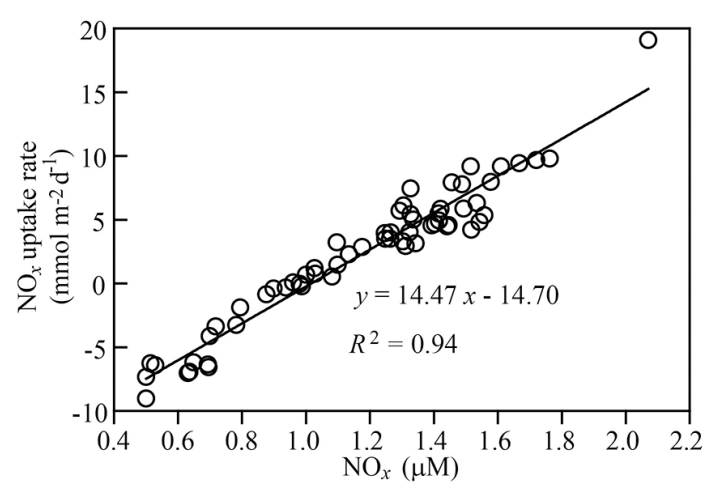

Figure 11. Uptake rate of $\mathrm{NO}_{x}$ against the concentration of $\mathrm{NO}_{x}$ in the water column at reef station $\mathrm{CT}$ in a spring-neap tide during 6-13 February 2012.

The uptake rate ranged from -9.04 to $19.1 \mathrm{mmol} \mathrm{m}^{-2} \mathrm{~d}^{-1}$, which compares well with the sum of nitrate and nitrite fluxes over Ningaloo Reef, a fringing reef in Australia, -24 to $15 \mathrm{mmol} \mathrm{m}^{-2} \mathrm{~d}^{-1}$ (Wyatt et al., 2012). It is significantly correlated with the concentration of $\mathrm{NO}_{x}$ in the water column (Fig. 11), with a slope of 14.5 and $R^{2}$ of $0.94(P<0.0001)$, indicating the mass-transfer limitation of $\mathrm{NO}_{x}$ uptake. The slope (in $\mathrm{md}^{-1}$ ) falls in the range of the typical uptake rate coefficient for dissolved inorganic nitrogen reported in Falter et al. (2004). Corals may be capable of adaptive changes in uptake kinetics depending on nutrient availability. However, the rate of nitrogen acquisition appeared to be influenced on a diel cycle in the coral reef system, presumably due to depletion of photosynthetic products during the night.

\subsection{Seasonal and regional extrapolations}

This study was carried out in winter. Seasonal variation is present in the river discharge as inferred from precipitation (Wang et al., 2005) and there might be an increase in the groundwater discharge and associated nutrient fluxes in summer as in other coastal systems (e.g., Lewis, 1987; Costa et al., 2006; Kelly and Moran, 2002; Wang et al., 2015). However, the relative changes in the groundwater discharge and associated nutrient fluxes would be much smaller than those of the river. The tidally driven feature of the groundwater discharge in this reef system might make our conclusions applicable to other seasons. But it is likely that what we observed in a dry season might be different from what would happen in a wet season due to the involvement of other forces, e.g., upwelling in summer (Wu et al., 2012b; Wang et al., 2016), which merits further studies.

In relatively oligotrophic coastal systems with coral reefs, such groundwater-associated nutrient fluxes may sustain the reef community production (Cuet et al., 2011), result in increases in diversity and occurrence of algae and sponge where relatively low salinity is present (Houk and Starmer, 2010), or induce the proliferation of diatom and cyanobac- 
teria (Blanco et al., 2011). In addition, groundwater tidally driven into nearshore ecosystems was found to be negatively correlated with seagrass habitat conditions (Houk et al., 2013). Nutrient loads via groundwater discharge may affect the community structure to move towards macroalgal blooms via bottom-up control (Lapointe, 1997) and likely play a role in the displacement of slow-growing benthic flora with fast-growing species observed in Sanya Bay in the last two decades (Titlyanov et al., 2015). Future changes in these fluxes, likely caused by climate change and human activities, might make the situation worse and need to be monitored in reef protection programs and be considered in assessing the environmental health of coral reef systems, especially in regions with expected higher inputs of anthropogenic nutrients into the groundwater.

\section{Conclusions}

The variability of nutrients in a spring-neap tidal cycle in a coral reef system in winter was revealed for the first time under the synergistic control of tidally driven groundwater discharge and biological processes. The activity of ${ }^{228} \mathrm{Ra}$ was significantly correlated with water depth and salinity, indicating tidally driven groundwater discharge at this site. Nitrate and phosphate were negatively correlated with salinity at the ebb flow of the spring tide, indicating that groundwater discharge was enriched in nitrate and phosphate. Nitrate, phosphate, and silicate in the water column showed greater diurnal variation during the spring tide than during the neap tide, while the diel change in the concentration of nitrite demonstrated no consistent pattern. The nutrient composition in the water column seemed to differ between the spring tide and neap tide but was similar to their biological uptake/release in either tidal period for oxidized nitrogen $\left(\mathrm{NO}_{x}\right)$ and phosphate. This similarity indicates that variation in nutrients in the water column in the reef system was mainly regulated by biological processes. However, correlations between $\mathrm{NO}_{x}$ and phosphate in the water column and between biologically contributed $\mathrm{NO}_{x}$ and phosphate were less significant during the spring tide when groundwater discharge was more prominent. The concentration of silicate in the water column was significantly correlated with that of $\mathrm{NO}_{x}$ during the neap tide, but they were not significantly correlated during the spring tide. This indicates that the composition of nutrients in the water column was also affected by tidally driven groundwater discharge, especially during the spring tide. Therefore, biological processes predominantly controlled the composition of nutrients in the reef system but that there was less of an impact in the spring tide due to groundwater discharge.

The stoichiometric relationship of $\mathrm{NO}_{x}$ and phosphate from the spring to neap tide in this reef system is important in understanding how biological processes predominantly affected these nutrients' variation under the influence of tidally driven groundwater discharge. The composition of silicate and $\mathrm{NO}_{x}$ during the neap tide when groundwater discharge was less prominent was comparable to the elemental ratio of diatoms. The release/consumption ratio of $\mathrm{NO}_{x}: \mathrm{P}$ by biological processes followed a Redfield-like ratio during the neap tide but was about one-third as much during the spring tide. Whether this change in the biological release/uptake ratio of $\mathrm{NO}_{x}: \mathrm{P}$ is associated with a change in the community structure needs further study.

Data availability. All the original data used in this work are provided either in Table 1 in the main text or in Table S1 in the Supplement.

The Supplement related to this article is available online at https://doi.org/10.5194/bg-15-997-2018-supplement.

Author contributions. GW and MD wrote the main text of the manuscript. GW, SW, ZW, WJ, YX, and ZZ collected samples in the field and measured the parameters. GW analyzed the data and did the calculations. ET drew some of the figures. WJ contributed in the project design and implementation, but deceased before paper submission. We regard her approval to this work as implicit.

Competing interests. The authors declare that they have no conflict of interest.

Acknowledgements. We thank the crew of the ship QiongLinGao 02706 and Junde Dong for arranging local logistic support and providing rainfall data. We appreciate the constructive comments from James Falter, Ramabadran Rengarajan, and one anonymous reviewer that have greatly improved the manuscript. This study was funded by MOST (2015CB954001) and the National Natural Science Foundation of China (41576074). John Hodgkiss is thanked for his assistance with English.

Edited by: S.W.A. Naqvi

Reviewed by: Ramabadran Rengarajan and one anonymous referee

\section{References}

Atkinson, M. J. and Smith, S. V.: C-N-P ratios of benthic marine plants, Limnol. Oceanogr., 28, 568-574, 1983.

Ayukai, T.: Retention of phytoplankton and planktonic microbes on coral-reefs within the great-barrier-reef, australia, Coral Reefs, 14, 141-147, 1995.

Ban, S. S., Graham, N. A., and Connolly, S. R.: Evidence for multiple stressor interactions and effects on coral reefs, Glob. Change Biol., 20, 681-697, 2014. 
Blanco, A. C., Watanabe, A., Nadaoka, K., Motooka, S., Herrera, E. C., and Yamamoto, T.: Estimation of nearshore groundwater discharge and its potential effects on a fringing coral reef, Mar. Pollut. Bull., 62, 770-785, 2011.

Brzezinski, M. A.: The Si-C-N ratio of marine diatoms - interspecific variability and the effect of some environmental variables, J. Phycol., 21, 347-357, 1985.

Burnett, W. C. and Dulaiova, H.: Estimating the dynamics of groundwater input into the coastal zone via continuous radon222 measurements, J. Environ. Radioactiv., 69, 21-35, 2003.

Costa Jr., O. S., Attrill, M. J., and Nimmo, M.: Seasonal and spatial controls on the delivery of excess nutrients to nearshore and offshore coral reefs of Brazil, J. Marine Syst., 60, 63-74, 2006.

Cuet, P., Atkinson, M. J., Blanchot, J., Casareto, B. E., Cordier, E., Falter, J., Frouin, P., Fujimura, H., Pierret, C., Susuki, Y., and Tourrand, C.: CNP budgets of a coral-dominated fringing reef at La Réunion, France: coupling of oceanic phosphate and groundwater nitrate, Coral Reefs, 30, 45-55, 2011.

D'Elia, C. F., Webb, K. L., and Porter, J. W.: Nitrate-rich groundwater inputs to Discovery Bay, Jamaica: a significant source of $\mathrm{N}$ to local coral reefs, B. Mar. Sci., 31, 903-910, 1981.

Dong, J.-D., Zhang, Y.-Y., Wang, Y. S., Wu, M.-L., Zhang, S., and Cai, C.-H.: Chemometry use in the evaluation of the sanya bay water quality, Braz. J. Oceanogr., 58, 339-352, 2010.

Falter, J. L., Atkinson, M. J., and Merrifield, M. A.: Mass-transfer limitation of nutrient uptake by a wave-dominated reef flat community, Limnol. Oceanogr., 49, 1820-1831, 2004.

Froelich, P. N., Bender, M. L., and Luedtke, N. A.: The marine phosphorus cycle, Am. J. Sci., 282, 474-511, 1982.

Genin, A., Monismith, S. G., Reidenbach, M. A., Yahel, G., and Koseff, J. R.: Intense benthic grazing of phytoplankton in a coral reef, Limnol. Oceanogr., 54, 938-951, 2009.

Han, A. Q., Dai, M. H., Kao, S. J., Gan, J. P., Li, Q., Wang, L. F., Zhai, W. D., and Wang, L.: Nutrient dynamics and biological consumption in a large continental shelf system under the influence of both a river plume and coastal upwelling, Limnol. Oceanogr., 57, 486-502, 2012.

Houk, P. and Starmer, J.: Constraints on the diversity and distribution of coral-reef assemblages in the volcanic Northern Mariana Islands, Coral Reefs, 29, 59-70, 2010.

Houk, P., Golbuu, Y., Gorong, B., Gorong, T., and Fillmed, C.: Watershed discharge patterns, secondary consumer abundances, and seagrass habitat condition in Yap, Micronesia, Mar. Pollut. Bull., 71, 209-215, 2013.

Jickells, T. D.: Nutrient biogeochemistry of the coastal zone, Science, 281, 217-222, 1998.

Kelly, R. P. and Moran, S. B.: Seasonal changes in groundwater input to a well-mixed estuary estimated using radium isotopes and implications for coastal nutrient budgets, Limnol. Oceanogr., 47, 1796-1807, 2002.

Lapointe, B. E.: Nutrient thresholds for bottom-up control of macroalgal blooms on coral reefs in Jamaica and southeast Florida, Limnol. Oceanogr., 42, 1119-1131, 1997.

Lewis, J. B.: Measurements of groundwater seepage flux onto a coral reef: spatial and temporal variations, Limnol. Oceanogr., 32, 1165-1169, 1987.

Li, X., Liu, S., Huang, H., Huang, L., Jing, Z., and Zhang, C.: Coral bleaching caused by an abnormal water temperature rise at Luhuitou fringing reef, Sanya Bay, China, Aquat. Ecosyst. Health, 15, 227-233, 2012.

Monismith, S. G., Davis, K. A., Shellenbarger, G. G., Hench, J. L., Nidzieko, N. J., Santoro, A. E., Reidenbach, M. A., Rosman, J. H., Holtzman, R., Martens, C. S., Lindquist, N. L., Southwell, M. W., and Genin, A. : Flow effects on benthic grazing on phytoplankton by a Caribbean reef, Limnol. Oceanogr., 55, 1881-1892, 2010.

Moore, W. S.: Radium isotope measurements using germanium detectors, Nucl. Instrum. Methods, 223, 407-411, 1984.

Papritz, A. and Stein, A.: Spatial prediction by linear kriging, in: Spatial Statistics for Remote Sensing, Remote Sensing and Digital Image Processing, Vol. 1, edited by: Stein, A., Van der Meer, F., and Gorte, B., Springer, Dordrecht, https://doi.org/10.1007/0-306-47647-9_6, 2002.

Paytan, A., Shellenbarger, G. G., Street, J. H., Gonneea, M. E., Davis, K., Young, M. B., and Moore, W. S.: Submarine groundwater discharge: an important source of new inorganic nitrogen to coral reef ecosystems, Limnol. Oceanogr., 51, 343-348, 2006.

Rama and Moore, W. S.: Using the radium quartet for evaluating groundwater input and water exchange in salt marshes, Geochim. Cosmochim. Ac., 60, 4645-4652, 1996.

Redfield, A. C.: The biological control of chemical factors in the environment, Sci. Prog., 11, 150-170, 1960.

Ribes, M., Coma, R., Atkinson, M. J., and Kinzie, R. A.: Sponges and ascidians control removal of particulate organic nitrogen from coral reef water, Limnol. Oceanogr., 50, 1480-1489, 2005.

Santos, I. R., Erler, D., Tait, D., and Eyre, B. D.: Breathing of a coral cay: tracing tidally driven seawater recirculation in permeable coral reef sediments, J. Geophys. Res., 115, C12010, https://doi.org/10.1029/2010JC006510, 2010.

Slomp, C. P. and Van Cappellen, P.: Nutrient inputs to the coastal ocean through submarine groundwater discharge: controls and potential impact, J. Hydrol., 295, 64-86, 2004.

Southwell, M. W., Weisz, J. B., Martens, C. S., and Lindquist, N.: In situ fluxes of dissolved inorganic nitrogen from the sponge community on Conch Reef, Key Largo, Florida, Limnol. Oceanogr., 53, 986-996, 2008.

Titlyanov, E. A. and Titlyanova, T. V.: Changes in the species composition of benthic macroalgal communities of the upper subtidal zone on a coral reef in Sanya Bay (Hainan Island, China) during 2009-2012, Russ. J. Mar. Biol., 39, 413-419, 2013.

Titlyanov, E. A., Titlyanova, T. V., Li, X., Hansen, G. I., and Huang, H.: Seasonal changes in the intertidal algal communities of Sanya Bay (Hainan Island, China), J. Mar. Biol. Assoc. UK, 94, 879-893, 2014.

Titlyanov, E. A., Titlyanova, T. V., Belous, O. S., and Kalita, T. L.: Inventory change (1990s-2010s) in the marine flora of Sanya Bay (Hainan Island, China), J. Mar. Biol. Assoc. UK, 95, 461470, 2015.

van der Zee, C., Roevros, N., and Chou, L.: Phosphorus speciation, transformation and retention in the Scheldt estuary (Belgium/the Netherlands) from the freshwater tidal limits to the North Sea, Mar. Chem., 106, 76-91, 2007.

Wang, G., Jing, W., Wang, S., Xu, Y., Wang, Z., Zhang, Z., Li, Q., and Dai, M.: Coastal acidification induced by tidal-driven submarine groundwater discharge in a coastal coral reef system, Environ. Sci. Technol., 48, 13069-13075, 2014. 
Wang, G., Wang, Z., Zhai, W., Moore, W. S., Li, Q., Yan, X., Qi, D., and Jiang, Y.: Net subterranean estuarine export fluxes of dissolved inorganic $\mathrm{C}, \mathrm{N}, \mathrm{P}, \mathrm{Si}$, and total alkalinity into the Jiulong River estuary, China, Geochim. Cosmochim. Ac., 149, 103-114, 2015.

Wang, G., Wang, S., and Wang, Z.: Significance of submarine groundwater discharge in nutrients budget in tropical Sanya Bay, China, Sustainability, 10, 380, https://doi.org/10.3390/su10020380, 2018.

Wang, H., Dong, J., Wang, Y., Chen, G., and Zhang, Y.: Variations of nutrient contents and their transportation estimate at Sanya Bay, J. Tropical Oceanogr., 25, 90-95, 2005.

Wang, Y., Jing, Z., and Qi, Y.: Coastal upwelling off eastern Hainan Island observed in the summer of 2013, Chinese J. Tropical Oceanogr., 35, 40-49, 2016.

Wu, M.-L., Zhang, Y.-Y., Dong, J.-D., Wang, Y.-S., and Cai, C.-H.: Identification of coastal water quality by self-organizing map in Sanya Bay, South China Sea, Aquat. Ecosyst. Health, 14, 291297, 2011.

Wu, M.-L., Ling, J., Long, L.-J., Zhang, S., Zhang, Y.-Y., Wang, Y.S., and Dong, J.-D.: Influence of human activity and monsoon dynamics on spatial and temporal hydrochemistry in tropical coastal waters (Sanya Bay, South China Sea), Chem. Ecol., 28, 375-390, 2012c.

Wu, M.-L., Zhang, Y.-Y., Dong, J.-D., Cai, C.-H., Wang, Y.-S., Long, L.-J., and Zhang, S.: Monsoon-driven dynamics of environmental factors and phytoplankton in tropical Sanya Bay, South China Sea, Oceanol. Hydrobiol. St., 41, 57-66, 2012a.
Wu, M.-L., Zhang, Y.-Y., Long, L.-J., Zhang, S., Wang, Y.-S., Ling, J., and Dong, J.-D.: Identification of coastal water quality, including heavy metals, in the South China Sea, Pol. J. Environ. Stud., 21, 1445-1552, 2012b.

Wyatt, A. S. J., Falter, J. L., Lowe, R. J., Humphries, S., and Waite, A. M.: Oceanographic forcing of nutrient uptake and release over a fringing coral reef, Limnol. Oceanogr., 57, 401-419, 2012.

Zhang, J., Wang, D. R., Jennerjahn, T., and Dsikowitzky, L.: Landsea interactions at the east coast of Hainan Island, South China Sea: a synthesis, Cont. Shelf Res., 57, 132-142, 2013.

Zhang, Q.: On biogeomorphology of Luhuitou fringing reef of Sanya city, Hainan Island, China, Chinese Sci Bull., 46, 97-101, 2001.

Zhao, M., Yu, K., Zhang, Q., Shi, Q., and Price, G. J.: Long-term decline of a fringing coral reef in the northern South China Sea, J. Coastal Res., 28, 1088-1099, 2012.

Zhao, X., Zhang, J., and Li, G.: Development of the Holocene coral reefs along the southern coast of Hainan Island, Sci. Geol. Sinica, 2, 150-160, 1983.

Zhou, W., Li, T., Cai, C., Huang, L., Wang, H., Xu, J., Dong, J., and Zhang, S.: Spatial and temporal dynamics of phytoplankton and bacterioplankton biomass in Sanya Bay, northern South China Sea, J. Environ. Sci., 21, 595-603, 2009. 